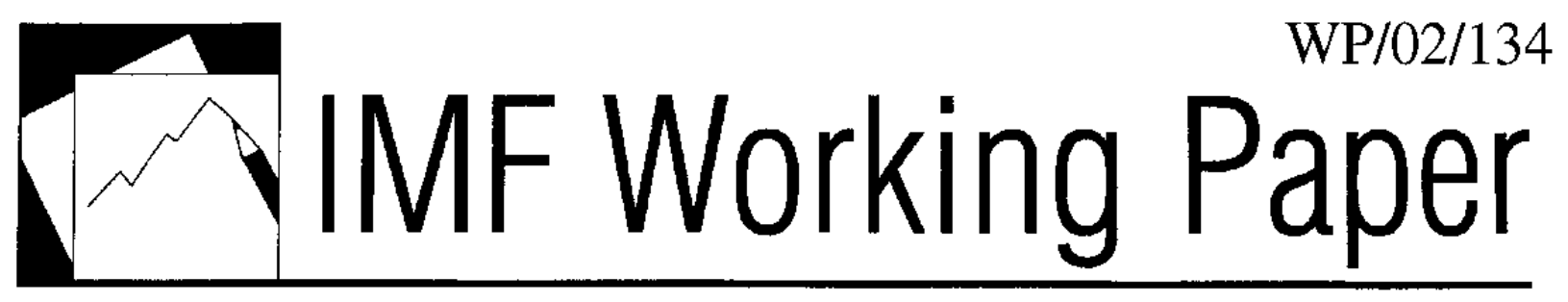

\title{
Regional Labor Market Disparities in Belgium
}

\author{
Marcello Estevão
}




\title{
IMF Working Paper
}

\author{
European I Department
}

\section{Regional Labor Market Disparities in Belgium}

\author{
Prepared by Marcello Estevão ${ }^{1}$ \\ Authorized for distribution by Robert Ford
}

August 2002

\begin{abstract}
The vicws expressed in this Working Paper are those of the author(s) and do not necessarily represent those of the IMF or IMF policy. Working Papers describe research in progress by the author(s) and are published to elicil comments and to further debate.
\end{abstract}

Regional labor market discrepancies have been widening in Belgium in the last two decades and are more evident within particular demographic groups. These developments can largely be accounted for by worse matching of people to jobs in the high-unemployment provinces. Using a structural VAR, it is also shown that labor market dynamics in Belgium produce a strong attenuating effect on employment growth, in contrast to the United States where initial labor demand shocks are expanded in the long run. After the short-run adjustment is over, there is less labor migration in Belgium than in the United States or Europe, corroborating the perception that Belgians move "too little."

JEL Classification Numbers: E24, J23, J60

Keywords: geography, labor, dynamics, divergences

Author's E-Mail Address: mestevao@imf.org

\footnotetext{
${ }^{1}$ I am grateful to Robert Ford and Antonio Spilimbergo for innumerous discussions and suggestions. Axel Behrens provided important clarifications of Eurostat data definitions. All errors and omissions should be attributed solely to me.
} 


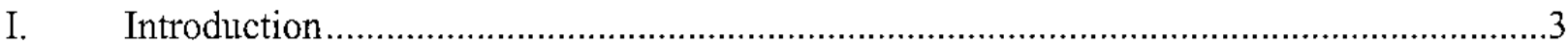

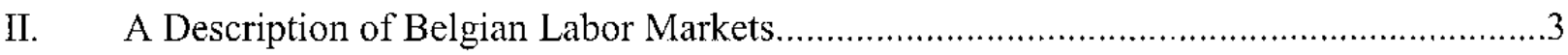

III. Analyzing Geographical Labor Market Disparities ...............................................6

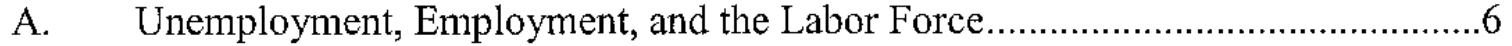

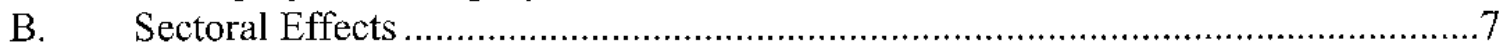

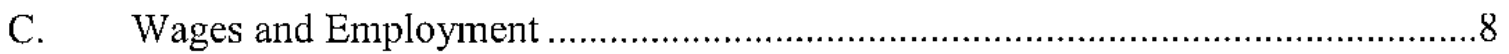

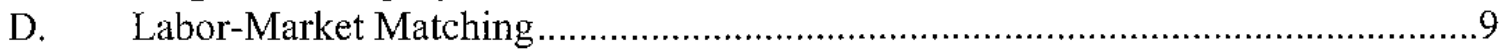

IV. Estimating the Dynamics of Labor Market Adjustment ............................................10

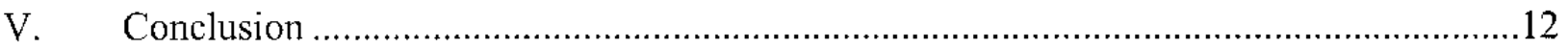

Tables

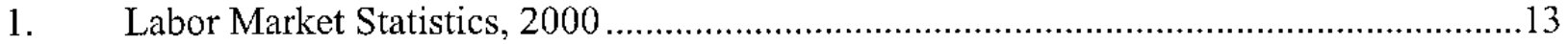

2. Decomposing Changes in the Unemployment Rate .................................................14

3. Decomposition of Employment Growth into Sector Performance

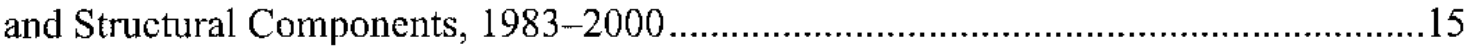

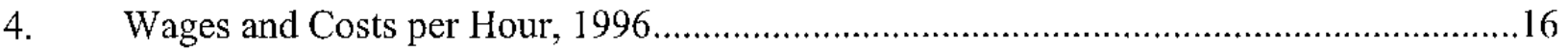

Figures

1. Geographic Dispersion in Unemployment Rates Within Selected Countries .................17

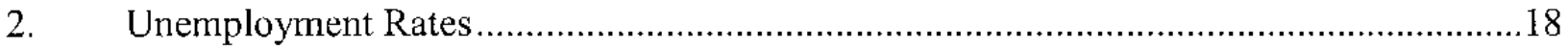

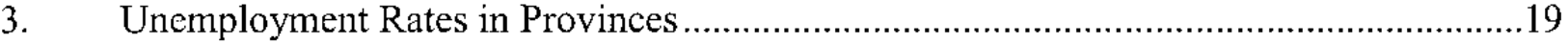

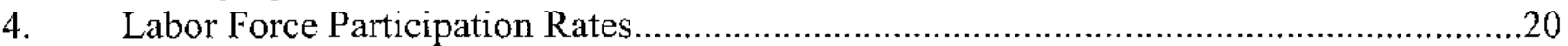

5. Labor Force Participation Rates in Provinces...........................................................21

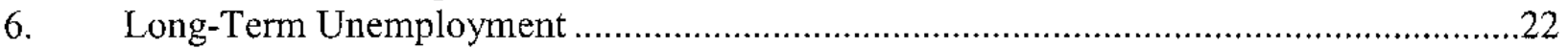

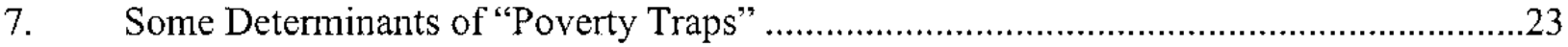

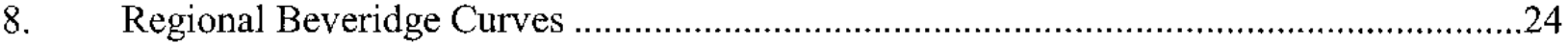

9. Response of Employment, Unemployment, and Labor Force Participation to an Employment Shock of 1 Percent.......................................................................25

Appendix I: Schematic Summary of Belgium's Geographical Organization..........................26

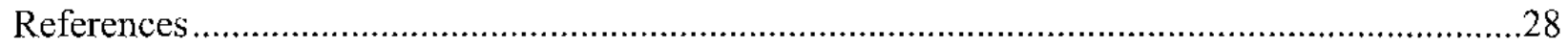




\section{INTRODUCTION}

As in some other countries - in Europe, for example, Germany has an east-west divide and Italy a north-south one-Belgium has significant geographical disparities in economic performance. Historically, the south of the country was richer and more dynamic than the north, but in the last several decades that situation has reversed. Output and employment growth in Flanders have surpassed those in Wallonia and, most starkly, the divergence in labor market performance has continually widened. This development may have important macroeconomic implications. The wide dispersion in unemployment rates may serve as an early brake on economic recovery as inflation picks up first in low-unemployment areas. Equally important, the existence of high- and low-unemployment areas in the same country suggests poor labor market efficiency in matching people to jobs and, consequently, a wasteful resource utilization. Finally, the chronically poor performance in some regions limits the degree to which national employment goals can be successful.

This paper examines labor market performance within Belgium and argues that a number of factors-poor worker-job matching, a compressed wage structure, and low geographical mobility-contribute to economic disparities. The next section describes the divergences in local labor markets in Belgium. Section III offers potential explanations for them, including an analysis of variations in the relationship between regional unemployment rates and regional vacancy rates (the Beveridge curve). Using a structural VAR framework, Section IV describes how labor markets adjust in Belgium and in its two main regions, taking previous work on the United States, Europe, and Spain as reference points. Section V concludes this paper.

\section{A DESCRIPTION OF Belgian LABOR MARKETS}

This section documents regional and provincial labor market dispersions within Belgium. On most dimensions, these disparities have increased substantially since the early $1980 \mathrm{~s}$. Notably, the coefficient of variation of local unemployment rates rose from 43.8 percent in 1990 to 57.8 percent in $2000 .^{2}$ To put this development in an international perspective, Belgium moved from the fifth to the second position in the list of European countries in terms of intranational unemployment rate variation (Figure 1).

Indeed, the most marked disparities across regions are in unemployment rates. Although they were similar at the beginning of the 1980s, unemployment rates in the three major Belgian regions-Brussels, Flanders, and Wallonia (see map in the appendix)-mave diverged, as the rate in Flanders fell significantly while those in the other two regions did not (Figure 2).

\footnotetext{
${ }^{2}$ The coefficients of variation refer to units of observation at the NUTS3 (nomenclature of statistical territorial units) level. For Belgium, these are within province-level units of observation, a definition close to "metropolitan areas." The order of the countries in Figure 1 is virtually unchanged if aggregation at the province level (NUTS2) is used.
} 
Within each region, experience has also varied. For instance, unemployment rates in the Walloon provinces of Walloon Brabant and Luxembourg remained below the national average throughout the period; and the Flemish province of Limburg left last position in 1983 , with an unemployment rate of 16 percent, to post a 5 percent unemployment rate in 2000, a remarkable reversal of fortune (Table 1 and Figure 3).

Longstanding differences also exist in labor force participation and employment rates. ${ }^{3}$ Since at least the late 1970s, participation rates have risen in Belgium but remained lower than in France or in Germany (Figure 4). Within Belgium, the participation rate in Flanders was $3 \frac{1}{4}$ percentage points above that in Wallonia in 2000 . In general, provinces with aboveaverage unemployment rates also have below average labor force participation rates (Figures 3 and 5). The Walloon Brabant province stands out by its significant increase in its labor force participation rate in the last few years, which by 2000 was the highest of any province and equal to the EU average. ${ }^{4}$

Using a more inclusive definition of "unemployed" does not alter significantly the impression of important and widening dispersion. CREW and IRES (1998) computes an "unemployment rate" which takes into account pre-retirement and older workers without jobs for social, family, or training reasons. ${ }^{5}$ This definition narrows, but does not eliminate, the disparity between Flanders and Wallonia, because the former makes greater use of preretirement and other measures to deal with joblessness. The disparity nevertheless increased markedly between 1983 and 1990 .

Examining various demographic groups also reveals important disparities. ${ }^{6}$ The unemployment rate of women has declined sharply in Belgium since the early $1980 \mathrm{~s}$, in contrast to the experience of France and Germany where it actually reached a peak only in the mid-1990s, though the decline in the Netherlands was much larger. Within Belgium, this

${ }^{3}$ The participation rate is the sum of employed and unemployed people (the labor force) divided by the working-age population. When referring to participation for Belgium, the regions, and the provinces, the working-age population is assumed to be between 15 and 75 years old, in line with Eurostat practice. However, for employment rates (the ratio of those employed to the working-age population), a working-age population of 15-64 years old is used, also in line with Eurostat practice (to match the definition used in European summits).

${ }^{4}$ EU averages refer to unweighted averages.

${ }^{5}$ Eurostat uses a traditional labor force survey-driven definition of unemployment: individuals without a job that are actively looking for one. Under this definition and using Eurostat data, the ratio between the Walloon and the Flemish unemployment rates was 1.84 in 1995 and 2.67 in 2000. Under the "broader" definition in CREW and IRES (1998) this ratio was 1.48 in 1995.

${ }^{6}$ For more detailed information, see Estevão (2002). 
rate declined in all three regions, but much more in Flanders than elsewhere. Within Flanders, Limburg stands out as having had the sharpest decline in women's unemployment rates, albeit from a very high starting point. Women's labor force participation rates trended up strongly in all three regions, if somewhat more so in Flanders, while men's labor force participation has trended down, also more strongly in Flanders causing the rates in the two regions to converge somewhat. The dispersion in youth unemployment rates is remarkable, with the difference between Flanders and Wallonia rising from 4 percentage points in 1993 to 18 percentage points in 2000 (Table 1). Again, there are significant differences among provinces within each region, especially Wallonia. By contrast, there is relatively little dispersion in youth participation rates between regions or provinces. Likewise, labor force participation among workers between 55 and 64 years of age, while low by international standards, is very similar between Flanders and Wallonia, and, once more, the dispersion among Walloon provinces is larger than in Flanders. In a reversal of the usual ranking, labor force participation among workers between 55 and 64 years of age has been lower in Flanders than in Wallonia since 1995, and in 2000 it reached 24.4 percent versus a 25.6 percent in Wallonia. This fact is another sign that Flanders has been more aggressive in the use of early-retirement policies than Wallonia.

Finally, long-term unemployment remains a serious national problem, and research suggests it reflects job-skill mismatches. As a fraction of total unemployment, long-term unemployment has fallen in Belgium (it remains high relative to most European countries), but has evolved largely in parallel across Belgian regions (Figure 6). Long-term unemployment is widely considered an important indicator of labor market performance and a particularly difficult policy problem. There are three key hypotheses regarding employment persistence at the individual level - that is, why the longer a person is unemployed, the harder it will be for him or her to become employed: human capital decline, signaling, and sorting. ${ }^{7}$ Dejemeppe and Cockx (1998) and CREW and IRES (1998) find that only observable individual characteristics matter - that is, the sorting hypothesis is the relevant one. This finding suggests that a mismatch between labor supply and demand is at the root of the problem. In addition, it casts doubt on the efficacy of programs designed to restore human capital or to remove the stigma of unemployment unless they also better match workers' skills to specific firms' needs. The issue of mismatch is taken up further at the end of Section III in the context of the Beveridge curve.

\footnotetext{
${ }^{7}$ The first would occur if unemployment gradually eroded general job skills, the second if firms (correctly or not) used the length of unemployment as a signal regarding (otherwise unobservable) employability, and the third if those who remain unemployed longer are just poorer prospects (the better ones having already been hired).
} 


\section{ANAlyzing Geographical Labor MARket Disparities}

\section{A. Unemployment, Employment, and the Labor Force}

Direct evidence on the relationship between unemployment, employment, and the labor force can be obtained by a decomposition of changes in the unemployment rate. The identity (where $P=$ working-age population, $L F R=$ labor force participation ratio, $N=$ employment level, $U=$ unemployment level, and the definition for the unemployment rate, $u=U /(N+U)$ ):

$P^{*} L F R=N+U$

yields the following approximate relationship: ${ }^{8}$

$d u \cong \frac{d P}{P}+\frac{d L F R}{L F R}-\frac{d N}{N}$

This decomposition illustrates that the much larger decline in the Flemish unemployment rate from 1983 to 2000 was mainly due to stronger employment creation (Table 2). Indeed, the "labor force effect" worked in the opposite direction, as the labor force grew more in Flanders than in Brussels or Wallonia. ${ }^{9}$ Breaking the sample into sub-periods of declining (1983-1991, 1996-2000) and increasing (1991-1996) aggregate unemployment rates shows that Flanders and Wallonia have similar employment experiences on the decline, but on the upswing Flanders produces more jobs. More formal estimates of regional labor market dynamics, using structural VAR estimations, are presented in Section IV.

${ }^{8}$ This final formula results from, first, using the unemployment definition in (1) to generate $P^{*} L F R=\frac{N}{(1-u)}$. Second, by taking the logarithm of this expression and differentiating it, one obtains $\frac{d P}{P}+\frac{d L F R}{L F R}=\frac{d N}{N}+\frac{d u}{(1-u)}$. Given that $u$ is a small number, equation (2) is obtained. Note that this approximation yields changes in the unemployment rate which are sometimes significantly different from the actual change (e.g., the calculations for Flanders for the period 1983-2000), but the relative differences across regions were roughly maintained.

${ }^{9}$ Labor force growth is the sum of the percent changes in working-age population and labor force participation rate. For Flanders this was 16.5 percent from 1983 to 2000, while for Wallonia and Brussels it was 12.1 percent and 3.7 percent. 


\section{B. Sectoral Effects}

The origin of the poor secular employment performance of Wallonia is probably the large economic shock suffered by the industrialized areas of the region between 1973 and 1980 . Certainly, there is substantial descriptive evidence to this effect. According to CREW and IRES (1998), between 1973 and 1995 Wallonia lost 50 percent of industry jobs compared to only 25 percent in Flanders. Eurostat data point to a loss of industry employment between 1975 and 2000 of about 37 percent in Wallonia, but 24 percent in Flanders. There is also some evidence that the fall in industry employment in Wallonia was more widespread than in Flanders, although sharp employment drops in the minerals and heavy metals industry (about 70 percent in Wallonia and 30 percent in Flanders between 1973 and 1985) was the biggest contributor to the poor record in the former. It is worth remarking that industry employment declined proportionately even more in Brussels than in Wallonia.

A more formal shift-share analysis suggests, however, that overall employment performance, rather than an initial adverse sectoral mix, accounts for the relatively weak history of employment growth in Wallonia. The difference in employment growth between regions can be decomposed as:

$$
d_{i j}=\sum_{k=1}^{n} \alpha_{i k}\left(\Delta n_{i k}-\Delta n_{j k}\right)+\sum_{k=1}^{n} \Delta n_{j k}\left(\alpha_{i k}-\alpha_{j k}\right)
$$

where $d_{i j}$ is the employment growth differential between regions $i$ and $j ; \forall_{i k}$ and $\forall_{j k}$ are the shares of sector $k$ employment in total employment in regions $i$ and $j$ at the beginning of the sample; and $\Delta n_{i k}$ and $\Delta n_{j k}$ are the growth rates in sector $k$ employment in regions $i$ and $j$. The first term on the right-hand side of (2) is the aggregate employment growth difference attributable to different rates of employment growth in each sector (that is, holding sectoral shares fixed), or the "sector performance" effect. The second term is the difference due to shifts in the relative sizes of the sectors (holding within-sector employment growth fixed), or the "structural" effect. The analysis, presented in Table 3, is based on a three-sector disaggregation (industry, services, and agriculture, forestry and fisheries), although results in CREW and IRES (1998) suggest the conclusions would largely hold up if more disaggregated data were used. ${ }^{10}$

The better employment record of Flanders relative to Wallonia is attributable to higher employment growth within each sector ("sectoral performance" effect), rather than sectoral shifts ("structural" effect). Indeed, the pattern of sectoral shifts slightly favors Wallonia. That

\footnotetext{
${ }^{10}$ Total employment growth in each region in Tables 2 and 3 may not match because the underlying data were obtained differently. In Table 2, total employment was derived from information for the unemployment rate and the level of unemployment, while sectoral employment data were obtained directly from Eurostat's community labor force survey.
} 
is, if each sector had had the same employment growth in both regions, overall employment growth in Wallonia would have been slightly higher. This result suggests that Wallonia's initially adverse industrial mix does not explain its relatively poor employment history, which must be ascribed to more pervasive weaknesses. ${ }^{11}$ The higher aggregate employment growth in Wallonia relative to Brussels is also mostly explained by the "sectoral performance" effect.

\section{Wages and Employment}

Notwithstanding the disparity in labor-market performance, wages appear to be relatively uniform across regions. In particular, Flanders and Wallonia have very similar levels of wages and salaries and labor costs, with Brussels having somewhat higher levels (Table 4). Also, the larger variability in unemployment rates within Wallonia has not been reflected in a larger coefficient of variation in labor costs. These impressions are reinforced by results, reported in CREW and IRES (1998), that the evolution of labor costs in industrial sub-sectors were similar across regions between 1975 and 1992, although variations were greater among white-collar than blue-collar workers. Using data from the Panel Study of Belgian Households for 1992, Docquier and Laurent (1996) and Docquier, Laurent and Perelman (1999) report that the probability of finding a job is larger in Flanders than in Wallonia, but the wage received does not depend on the region of residence. These results were confirmed by Delhausse and Guio (2001), using microeconomic data for $1995 .^{12}$

Four factors may explain this wage compression. First, the small size of the country makes for easy comparisons across regions. As a result, firms may have difficulty differentiating wages without generating resentment. Second, there has historically been a strong sense of social solidarity in Belgium, which tends to limit wage dispersion in all dimensions (including geographical) so as not to unduly widen the income distribution. Third, the wage bargaining process has an important national component, with an eye to internalizing the macroeconomic effects of wage settlements and, in particular, maintain international cost

${ }^{11}$ It may have been, however, that the initial industry mix resulted in a larger initial economic shock, which exposed labor-market weaknesses more in Wallonia than elsewhere.

12 These studies estimate wage equations for Belgium controlling for individuals' observed characteristics, including region of residence. They found that the coefficient for the regional dummy variable is not significantly different from zero and, therefore, that observed differences in wages across regions are determined by the composition of their labor force. This result is remarkable because the studies do not control for differences in regional business cycles since they are based on a cross-section of data with no time series variation. In that situation, the regional dummy included in the regression specification would be also capturing the relative business cycle position of each region. Given that unemployment rates in Flanders were much smaller than in Wallonia both in 1992 and in 1995, the years used in the estimation process, one would expect a negative premium for workers in Wallonia. 
competitiveness. National wage norms, generally negotiated through the so-called Interprofessional Agreement, are meant to set limits on subsequent sectoral and firm-level labor agreements. Even though flexibility occurs at these lower levels, sectoral negotiations often span geographical areas and seldom include clauses dealing with divergences in local labor markets; negotiations at the company level, at least until recently, seem to not have deviated strongly from the sectoral agreements. Finally, the extensive benefits system and the minimum wage may contribute to wage compression by placing a floor on wages, especially in areas with the weakest labor demand. However, both unemployment benefit replacement rates and the minimum wage have been declining relative to market wages in Belgium, and are not especially high by European standards (Figure 7). On the other hand, statutory income tax rates on low-wage earners remain relatively high in Belgium, which reduces the reward to work.

The general perception is that labor mobility is too low to compensate for the lack of wage differentiation. That is, while regional labor markets could clear if those in the labor force in high-unemployment areas migrated to (or took jobs in) low-unemployment areas. However, policy makers and researchers believe that there is relatively little geographic mobility in Belgium. In part, this reflects linguistic and cultural differences between Flanders and Wallonia, but these would not account for the large variation in unemployment rates across Walloon provinces. Of course, generous social benefits and lack of wage dispersion could contribute to low mobility, as both reduce the benefits of moving.

\section{Labor Market Matching}

This sub-section investigates more fully the issue of job mismatch, raised above. A wellknown aggregate measure of mismatch is the Beveridge Curve, the ratio of job vacancies to the unemployment rate. A rightward shift in the Beveridge Curve-a higher unemployment rate for the same number of vacancies-suggests a poorer match of workers to available jobs, as the economy "needs" to generate more vacancies to fill a fixed number of jobs. By contrast, business cycles ought to generate a negative relationship between the vacancy rate and the unemployment rate as, for instance, an expansion creates many new vacancies, some of which are filled from the ranks of the unemployed. Beveridge curves for Belgium and the three regions are plotted in Figure 8.

The shifts in Beveridge curves in each region are consistent with a larger mismatch between jobs and skills in Wallonia than in Flanders. Based on national sources for regional unemployment rates from 1970 to 1983 and on Eurostat data after that, the vacancy- 
unemployment tradeoff deteriorated between the early 1970 s and 1983 in both regions. ${ }^{13}$ After that, the situation appears to improve significantly in Flanders, but much less so in Wallonia. In the late 1990s, the tradeoff deteriorated further in Wallonia, whereas in Flanders vacancies rose to record highs, which is consistent with a very tight labor market there. The possibility of worse skill mismatch in Wallonia than in Flanders probably also lies behind the widening regional gap in the share of long-term unemployment in total unemployment discussed in the previous section.

\section{Estimating the Dynamics OF Labor MARKeT AdJUSTMENT}

This section provides a formal econometric analysis of Belgian labor-market dynamics using a structural vector autoregression approach. The methodology is the same as that used by Blanchard and Katz (1992) for U.S. states. ${ }^{14}$ The vector autoregression (VAR) has equations for employment growth, the ratio of employment to labor force, and the labor force participation rate. The system is simulated to assess the adjustment of these variables to a local labor demand shock. The equations are:

$$
\begin{aligned}
& \Delta n_{i t}=a_{i 1}+b_{1}(L) \Delta n_{i t-1}+c_{1}(L) e l_{i t-1}+d_{1}(L) l f p_{i t-1}+\varepsilon_{i 1 t} \\
& e l_{i t}=a_{i 2}+b_{2}(L) \Delta n_{i t}+c_{2}(L) e l_{i t-1}+d_{2}(L) l f p_{i t-1}+\varepsilon_{i 2 t} \\
& l f p_{i t}=a_{i 3}+b_{3}(L) \Delta n_{i t}+c_{3}(L) e l_{i t-1}+d_{3}(L) l f p_{i t-1}+\varepsilon_{i 3 t}
\end{aligned}
$$

where all variables are differences between province $i$ at time $t$, and the national average, in order to capture regional dynamics as opposed to regional movements that are caused by aggregate business cycles; $\Delta n_{i t}$ is the difference of the logarithm of employment; $e l_{i t}$ is the logarithm of the ratio of employment to the labor force; and $l f p_{i t}$ is the logarithm of the labor force participation rate. The data are pooled across time and provinces, but province-specific dummies are used to capture long-term level differences. As in Blanchard and Katz (1992), two lags of each variable are included in the right-hand side of the equations, to capture the feedback of each of these variables on the others. The specification of the lag structure allows current changes in employment to affect current changes in the employment/labor force ratio and in labor force participation, but not vice-versa. Also, current innovations in provincial

${ }^{13}$ The series for regional unemployment was obtained by extrapolating Eurostat data backwards from 1983 with information in CREW-IRES (1998). Vacancies data from 1983 on were obtained from the web page of the Belgian Central Bank (BNB) and extrapolated backwards using information from CREW-IRES (1998). This exercise should be viewed with caution because of possible differences in definitions in these different sources of data. However, the regional graphs of the unemployment/vacancy relationship match charts in other research papers ending at the beginning of the 1990s.

${ }^{14}$ This methodology has also been applied by Decressin and Fatás (1995) to Europe, and Bentolila and Jimeno (1995) and Mauro and Spilimbergo (1999) to Spain. 
employment growth, $\varepsilon_{i l t}$, are assumed to capture an innovation in labor demand. This is a plausible assumption as long as these unexpected changes are not due to exogenous changes in labor supply or migration. With these two assumptions, the effects of a positive local labor demand shock (an increase in provincial employment vis-à-vis the national average) can be traced through time using the impulse-response charts based on the estimated parameters of the system of equations. Here the focus is on the unemployment rate (or minus the logarithm of the ratio employment/labor force); migration is obtained by residual using equation (2) as demographics are assumed not to be affected by the shock. ${ }^{15}$

The estimates imply a more muted longer-term employment response in Belgium than elsewhere. After the short-run dynamics have played out, relative provincial employment in Belgium is only 0.38 percent above the pre-shock level (Figure 9), compared to 1.3 percent for U.S. states (Blanchard and Katz (1992)) and 0.6 percent of European countries (Decressin and Fatás (1995)). The short-run dynamics also point to lower migration immediately after a labor demand shock than in the United States or Spain, but not in Europe as a whole. In Belgium, more than 50 percent of the adjustment to the labor demand shock in the first year occurs through an increase in labor force participation, perhaps because many of those outof-the labor force are discouraged workers waiting for a better opportunity to find a job.

The speed of labor market adjustment is similar in Belgium to the United States or Europe, and the unemployment rate plays a small role. For the United States, Europe, and Belgium, the variables studied converge to their steady-state levels after about 5 to 7 years. In all cases, unemployment rates seem to vary little when compared to the other variables. In the United States most of the adjustment is done via migration in all years, in Europe the adjustment is done mostly via increases in labor force participation rates in the first two years while migration begins to play a larger role in the third year, and, in Belgium, there is an initial spike in labor force participation, but then the employment response falls off in the second year. ${ }^{16}$ However, the similar speeds of adjustment do not necessarily mean that each of these labor markets is equally flexible, but rather that the speed of adjustment to regional shocks is similar. As noted above, in Belgium this adjustment involves relatively little employment response.

Overall, employment in the Flemish region responds more to an initial labor demand shock than in the Walloon region, which might be related to larger intra-regional labor mobility. To

${ }^{15}$ Many different specifications for the system of equations (4), (5) and (6) were tested. The use of time-dummies instead of defining each variable as a deviation to the national average barely changes the impulse-response charts. When higher-order lags for the regressors were used the results did not change much but labor force participation proved to be a bit more volatile than shown in Figure 9.

${ }^{16}$ After an increase of 1 percent in the first year, employment in the second year of adjustment is only 0.52 percent above its pre-shock level. 
assess the final impact of a temporary labor demand shock in each region, as well as the relative importance of intra-regional migration, the same methodology can be applied to the provinces within Wallonia and Flanders separately. In this case, the variables are defined as differences from the regional averages and should be interpreted as the adjustment in provincial labor markets when employment in a province grows one percent faster than the regional average. After the shock, Flemish provinces tend to experience a larger employment increase than Walloon provinces (Figurc 9). After three years, the adjustment dynamics in the two regions are similar, but employment is 0.45 percent above its initial value in Flanders, and 0.38 percent above in Wallonia. Since unemployment and labor force participation return to their initial levels, this higher employment must come through greater migration.

\section{Conclusion}

Labor market performance differs sharply across Belgian geographical areas. Differences are especially large among particular groups, and the gaps have widened over time. Labor market performance in the lagging areas accounts for Belgium's poor showing relative to the EU, and if not corrected is likely to prevent Belgium from achieving the objectives set at the Lisbon Summit. The main policy issues are how best to attract firms to high-unemployment areas and labor to the low-unemployment areas. Regional industrial policies and wage and income policies can be used to achieve these goals.

Poor job matching, wage compression, and low mobility are all likely reasons for persistent regional differences. The labor market impediments facing the poorly performing areas appear to be pervasive, going beyond unfavorable initial conditions of twenty years ago. Vacancies evidence suggests a worsening job mismatch problem, particularly in Wallonia. So policy should focus on training and the educational system more generally. The centralized aspects of wage bargaining contribute to wage compression, though there are other important factors involved. Wage reductions in depressed areas will not raise employment much if there are large disincentives to work in the form of generous welfare benefits, an issue most acute at low wage rates. Low geographical mobility is probably partly due to blunted economic incentives, although there are also important linguistic and cultural factors. Compared with other countries for which the same type of analysis has been made, employment in Belgium tends to be less sensitive to labor demand shocks, although the speed of adjustment of Belgian labor markets to region-specific shocks is similar. Employment in Flanders is more sensitive to initial labor demand shocks than employment in Wallonia. 
Table 1. Labor Market Statistics, 2000

(In percent)

\begin{tabular}{|c|c|c|c|c|c|c|c|c|c|c|c|}
\hline & \multicolumn{6}{|c|}{ Labor Force Participation ${ }^{1}$} & \multicolumn{5}{|c|}{ Unemployment } \\
\hline & Total & Men & Women & Young $^{2}$ & Prime age ${ }^{3}$ & Older $^{4}$ & Total & Men & Women & $\begin{array}{l}\text { Less than } \\
25 \text { years }\end{array}$ & $\begin{array}{l}25 \text { or more } \\
\text { years of age }\end{array}$ \\
\hline Belgium & 52.3 & 61.5 & 43.6 & 35.7 & 82.7 & 10.9 & 6.7 & 5.4 & 8.4 & 16.0 & 5.7 \\
\hline Brussels & 51.6 & 61.9 & 42.4 & 29.1 & 80.1 & 13.9 & 11.1 & 10.3 & 12.3 & 28.1 & 9.5 \\
\hline Flanders & 53.5 & 62.1 & 45.3 & 38.0 & 85.0 & 10.5 & 4.0 & 3.1 & 5.3 & 8.9 & 3.4 \\
\hline Antwerp & 51.8 & 61.3 & 42.8 & 35.5 & 83.2 & 9.6 & 4.6 & 3.6 & 6.0 & 10.3 & 4.0 \\
\hline Limburg & 52.5 & 62.5 & 42.5 & 38.2 & 79.4 & 10.3 & 5.0 & 3.0 & 7.8 & 9.8 & 4.4 \\
\hline East Flanders & 53.9 & 62.2 & 46.1 & 39.1 & 85.9 & 10.1 & 4.3 & 3.4 & 5.3 & 10.0 & 3.6 \\
\hline Flemish Brabant & 55.4 & 62.2 & 48.9 & 32.8 & 88.3 & 12.2 & 2.9 & 2.4 & 3.5 & 7.5 & 2.4 \\
\hline West Flanders & 54.4 & 62.7 & 46.5 & 44.3 & 87.7 & 11.2 & 3.3 & 2.4 & 4.3 & 6.4 & 2.8 \\
\hline Wallonia & 50.3 & 60.3 & 41.1 & 33.8 & 79.5 & 10.5 & 10.7 & 8.6 & 13.5 & 26.7 & 8.9 \\
\hline Walloon Brabant & 56.0 & 62.7 & 49.8 & 26.1 & 88.3 & 12.3 & 6.5 & 5.3 & 7.8 & 21.7 & 5.3 \\
\hline Hainaut & 48.2 & 59.1 & 38.4 & 35.8 & 75.5 & 9.4 & 13.1 & 10.6 & 16.7 & 29.9 & 11.0 \\
\hline I.jège & 49.4 & 58.6 & 41.0 & 33.0 & 79.3 & 9.8 & 10.9 & 8.7 & 13.6 & 27.4 & 9.0 \\
\hline Luxembourg & 54.0 & 64.8 & 43.6 & 37.2 & 83.9 & 12.0 & 5.5 & 4.0 & 7.5 & 14.7 & 4.4 \\
\hline Namur & 52.0 & 63.5 & 41.4 & 33.8 & 82.1 & 10.5 & 10.2 & 8.1 & 13.0 & 26.6 & 8.3 \\
\hline Germany & 57.5 & 66.7 & 48.9 & 50.4 & 85.4 & 21.0 & 8.1 & 7.9 & 8.5 & 8.9 & 8.0 \\
\hline France & 55.7 & 63.0 & 49.1 & 35.6 & 86.4 & 12.8 & 9.6 & 8.0 & 11.5 & 18.8 & 8.6 \\
\hline Netherlands & 63.5 & 73.2 & 54.1 & 72.2 & 83.6 & 18.4 & 2.8 & 2.1 & 3.8 & 5.1 & 2.4 \\
\hline European Union (15) & 56.0 & 65.8 & 46.9 & 47.5 & 82.4 & 18.6 & 8.4 & 7.2 & 9.9 & 16.1 & 7.3 \\
\hline
\end{tabular}

Sources: Statistical Yearbook 2001, Eurostat; and IMF staff calculations.

${ }^{1}$ According to Eurostat definition, the relevant age group for the calculation of labor force participation are pcople between 15 and 75 years of age.

It is important to remark that Eurostat data for the employment rate (employment divided by working-age population) refer to people between 15 and 64 years of age. Therefore, a direct comparison between the two statistics as reported in Eurostat - Cronos database will show employment rates above labor force participation rates.

${ }^{2}$ Individuals between 15 and 24 years of age.

${ }^{3}$ Individuals between 25 and 54 years of age.

${ }^{4}$ Individuals between 55 and 75 years of age. 
Table 2. Decomposing Changes in the Unemployment Rate ${ }^{1}$

(In percentage points)

\begin{tabular}{|c|c|c|c|c|}
\hline & Belgium & Brussels & Flanders & Wallonia \\
\hline & \multicolumn{4}{|c|}{$1983-2000$} \\
\hline Working-age population & 3.9 & 1.9 & 5.3 & -1.1 \\
\hline Labor force participation rate & 10.7 & 1.8 & 11.2 & 13.2 \\
\hline Employment & 21.8 & 6.1 & 26.7 & 14.3 \\
\hline Approximate changes in unemployment rate & -7.2 & -2.4 & -10.2 & -2.2 \\
\hline \multirow[t]{2}{*}{ Actual changes in unemployment rate } & -5.2 & -2.0 & -7.3 & -1.8 \\
\hline & \multicolumn{4}{|c|}{ 1983-91 } \\
\hline Working-age population & 3.8 & 0.1 & 5.5 & 1.7 \\
\hline Labor force participation rate & -1.2 & -4.9 & -1.7 & 1.3 \\
\hline Employment & 9.3 & 1.1 & 11.8 & 7.5 \\
\hline Approximate changes in unemployment rate & -6.7 & -5.8 & -8.0 & -4.5 \\
\hline \multirow[t]{2}{*}{ Actual changes in unemployment rate } & -5.8 & -5.3 & -6.9 & -3.8 \\
\hline & \multicolumn{4}{|c|}{$1991-96$} \\
\hline Working-age population & 0.5 & -3.3 & 1.1 & 2.5 \\
\hline Labor force participation rate & 2.2 & 1.0 & 2.6 & 1.8 \\
\hline Employment & 1.0 & -6.5 & 2.7 & 2.5 \\
\hline Approximate changes in unemployment rate & 1.7 & 4.2 & 1.1 & 1.8 \\
\hline \multirow[t]{2}{*}{ Actual changes in unemployment rate } & 1.5 & 3.8 & 1.0 & 1.6 \\
\hline & \multicolumn{4}{|c|}{$1996-2000$} \\
\hline Working-age population & 1.5 & 4.3 & 1.4 & -2.4 \\
\hline Labor force participation rate & 4.9 & 1.7 & 5.1 & 6.3 \\
\hline Employment & 9.9 & 9.7 & 10.1 & 6.3 \\
\hline Approximate changes in unemployment rate & -3.5 & -3.7 & -3.6 & -2.5 \\
\hline Actual changes in unemployment rate & -2.9 & -2.9 & -3.1 & -2.2 \\
\hline
\end{tabular}

Sources: Eurostat; and IMF staff calculations.

Original Eurostat data for the level and the rate of unemployment and the employment rate were used to obtain employment levels, labor force participation rate, and working-age population. 
Table 3. Decomposition of Employment Growth into Sector Performance and Structural Components, 1983-2000

\begin{tabular}{|c|c|c|c|c|c|}
\hline & \multicolumn{2}{|c|}{$\begin{array}{l}\text { Employment Growth } \\
\text { (In percent) }\end{array}$} & \multirow[t]{2}{*}{ Difference } & \multirow[t]{2}{*}{$\begin{array}{l}\text { Sector Performance } \\
\text { (In percent }\end{array}$} & \multirow[t]{2}{*}{$\begin{array}{l}\text { Structural Effect } \\
\text { points) }\end{array}$} \\
\hline & Waflonia & Flanders & & & \\
\hline 'lotal & 17.4 & 25.6 & -8.3 & -11.0 & 2.7 \\
\hline Industry & -9.2 & -3.9 & -5.3 & $\ldots$ & $\ldots$ \\
\hline \multirow[t]{2}{*}{ Services } & 33.3 & 47.2 & -13.9 & $\ldots$ & $\ldots$ \\
\hline & Wallonia & Brussels & & & \\
\hline Total & 17.4 & 0.8 & 16.5 & 22.2 & -5.7 \\
\hline Industry & -9.2 & -30.0 & 20.8 & $\ldots$ & $\ldots$ \\
\hline \multirow[t]{2}{*}{ Services } & 33.3 & 9.1 & 24.2 & $\cdots$ & $\ldots$ \\
\hline & Flanders & Brussels & & & \\
\hline Total & 25.6 & 0.8 & 24.8 & 32.3 & -7.5 \\
\hline Industry & -3.9 & -30.0 & 26.1 & $\ldots$ & $\ldots$ \\
\hline \multirow[t]{2}{*}{ Services } & 47.2 & 9.1 & 38.0 & $\ldots$ & $\ldots$ \\
\hline & Wallonia & Belgium & & & \\
\hline Total & 17.4 & 20.6 & -3.2 & -3.9 & 0.7 \\
\hline Industry & -9.2 & -7.0 & -2.2 & $\ldots$ & $\ldots$ \\
\hline \multirow[t]{2}{*}{ Services } & 33.3 & 38.0 & -4.7 & $\ldots$ & $\ldots$ \\
\hline & Flanders & Belgium & & & \\
\hline Total & 25.6 & 20.6 & 5.0 & 6.7 & -1.7 \\
\hline Industry & -3.9 & -7.0 & 3.1 & $\ldots$ & $\ldots$ \\
\hline Services & 47.2 & 38.0 & 9.2 & $\ldots$ & $\ldots$ \\
\hline
\end{tabular}

Sources: Eurostat, Labor Force Survey; and IMF staff calculations. Data for industry and services subsectors are not readily available. Calculations for agriculture, forestry, and fisheries were omitted. 
Table 4. Wages and Costs per Hour, 1996

Industry and services (excluding public administration) ${ }^{1}$

\begin{tabular}{|c|c|c|c|c|}
\hline & $\begin{array}{l}\text { Direct Remuneration and } \\
\text { Bonus }\end{array}$ & $\begin{array}{l}\text { Wages and } \\
\text { Salaries }\end{array}$ & \multicolumn{2}{|c|}{ Labor Costs } \\
\hline & & & & $\begin{array}{l}\text { Coefficient of } \\
\text { variation } \\
\text { (In percenl) }\end{array}$ \\
\hline Belgium & 14.36 & 17.06 & 25.00 & 36.84 \\
\hline Brussels & 16.59 & 19.28 & 28.71 & 39.07 \\
\hline Flanders & 14.05 & 16.81 & 24.43 & 36.04 \\
\hline Wallonia & 13.61 & 16.17 & 23.88 & 33.29 \\
\hline France & 12.92 & 14.99 & 22.33 & 41.92 \\
\hline Netherlands & 11.59 & 15.41 & 20.39 & 39.73 \\
\hline
\end{tabular}

Sources: Eurostat; and IMF staff calculations.

'Estimated from the 1996 structure of earnings survey of the National Statistics Institute as reported by Furostat. Levels are expressed in European Currency Units (ECU). Labor costs = wages and salaries - employer's social security contributions + raining costs +others.

Wages and salaries = direct remuneration and bonus + payments to employees saving schemes, payment for days not worked and payments in kind. 
Figure 1. Geographic Dispersion in Unemployment Rates Within Selected Countries (Unit of observation: NUTS3 Level)

Coefficient of Variation in 2000

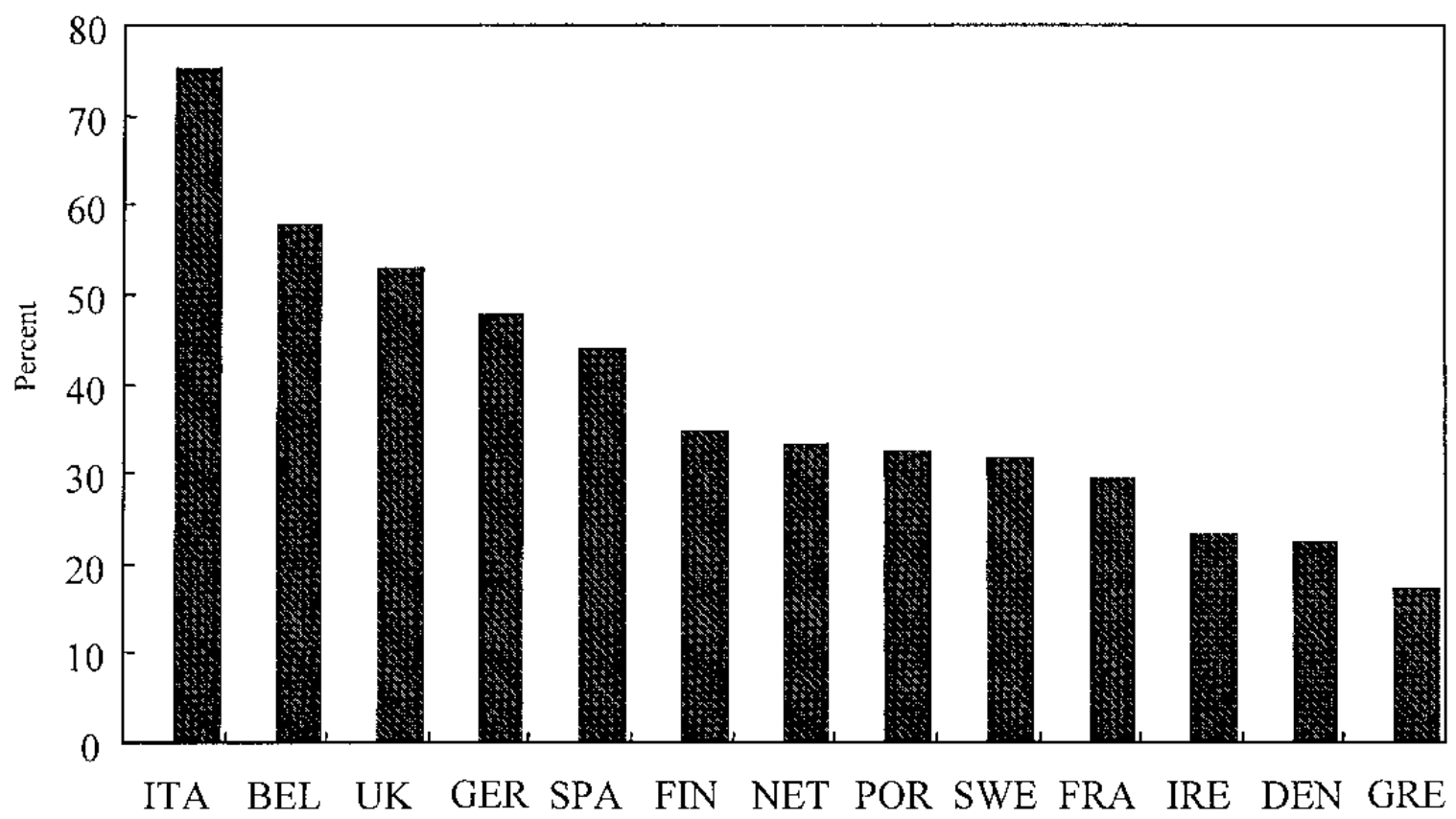

Coefficient of Variation in 1990

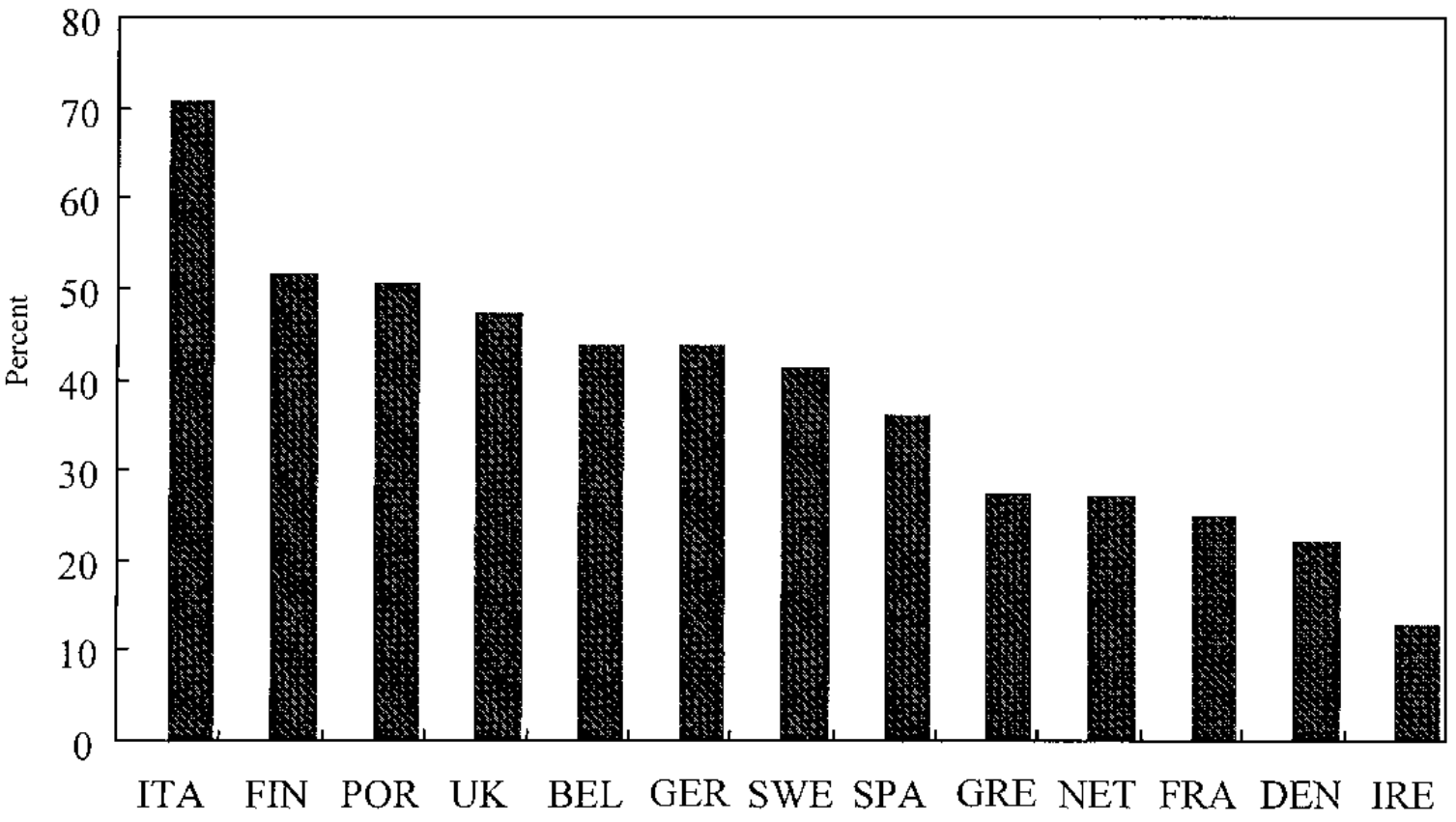


Figure 2. Unemployment Rates
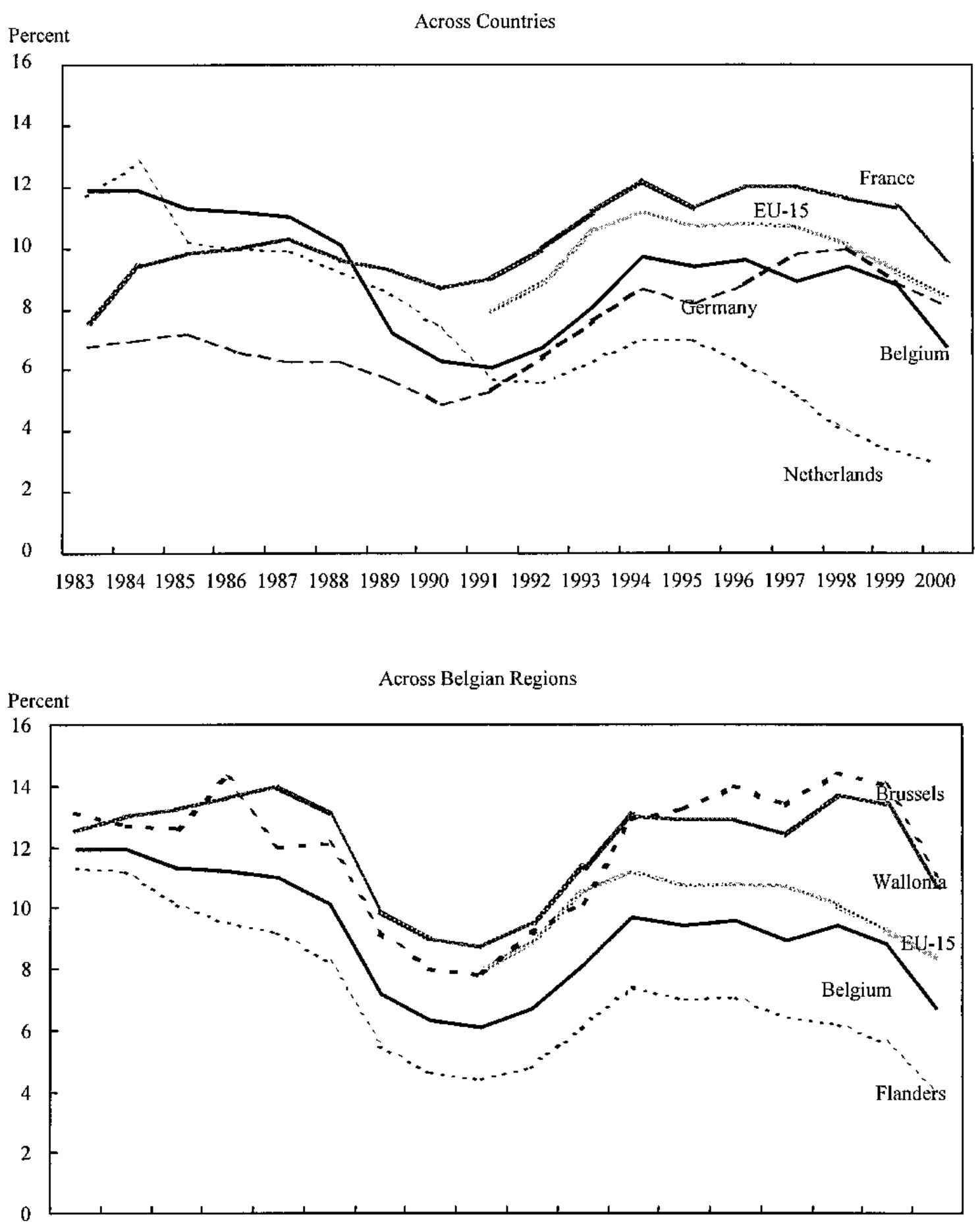

198319841985198619871988198919901991199219931994199519961997199819992000

Source: Eurostat. 
Figure 3. Unemployment Rates in Provinces
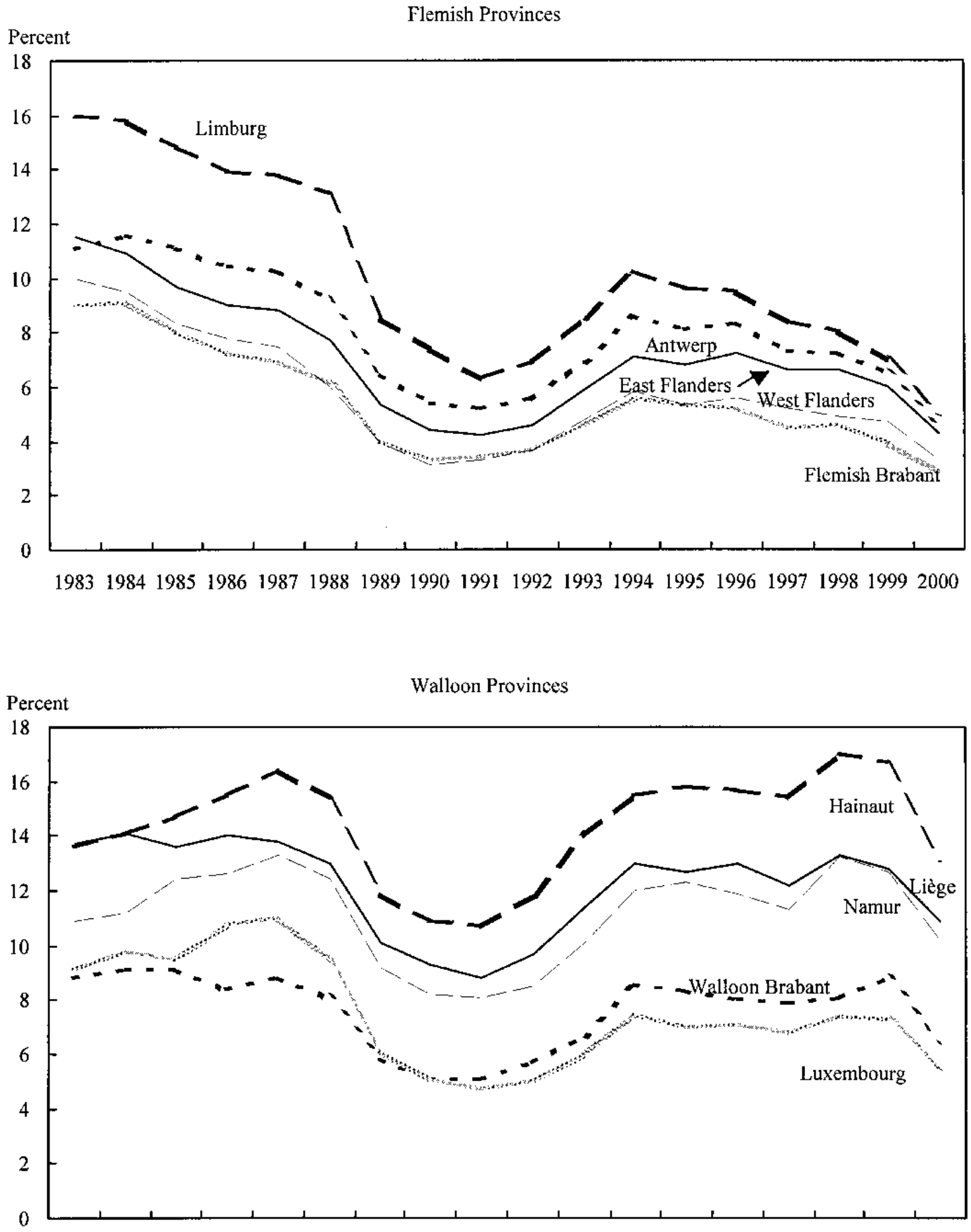

198319841985198619871988198919901991199219931994199519961997199819992000 Source: Eurostat. 
Figure 4. Labor Force Participation Rates
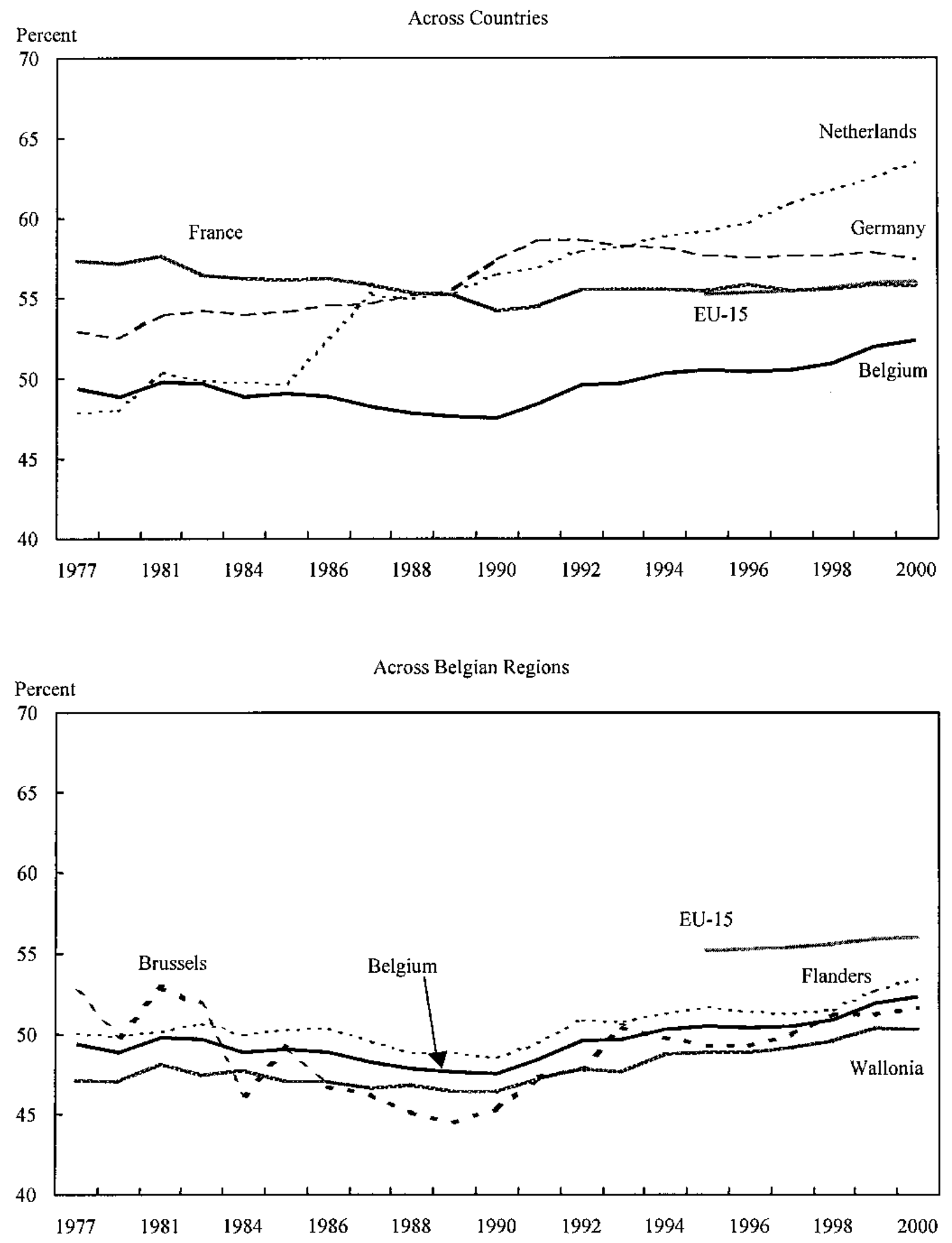

Source: Eurostat. Labor force participation rates are defined as the sum of employed and unemployed individuals divided by working-age population. Reference group is comprised of individuals between 15 and 75 years of age. Data for 1978,1980 , and 1982 are not readily available. 
Figure 5. Labor Force Participation Rates in Provinces
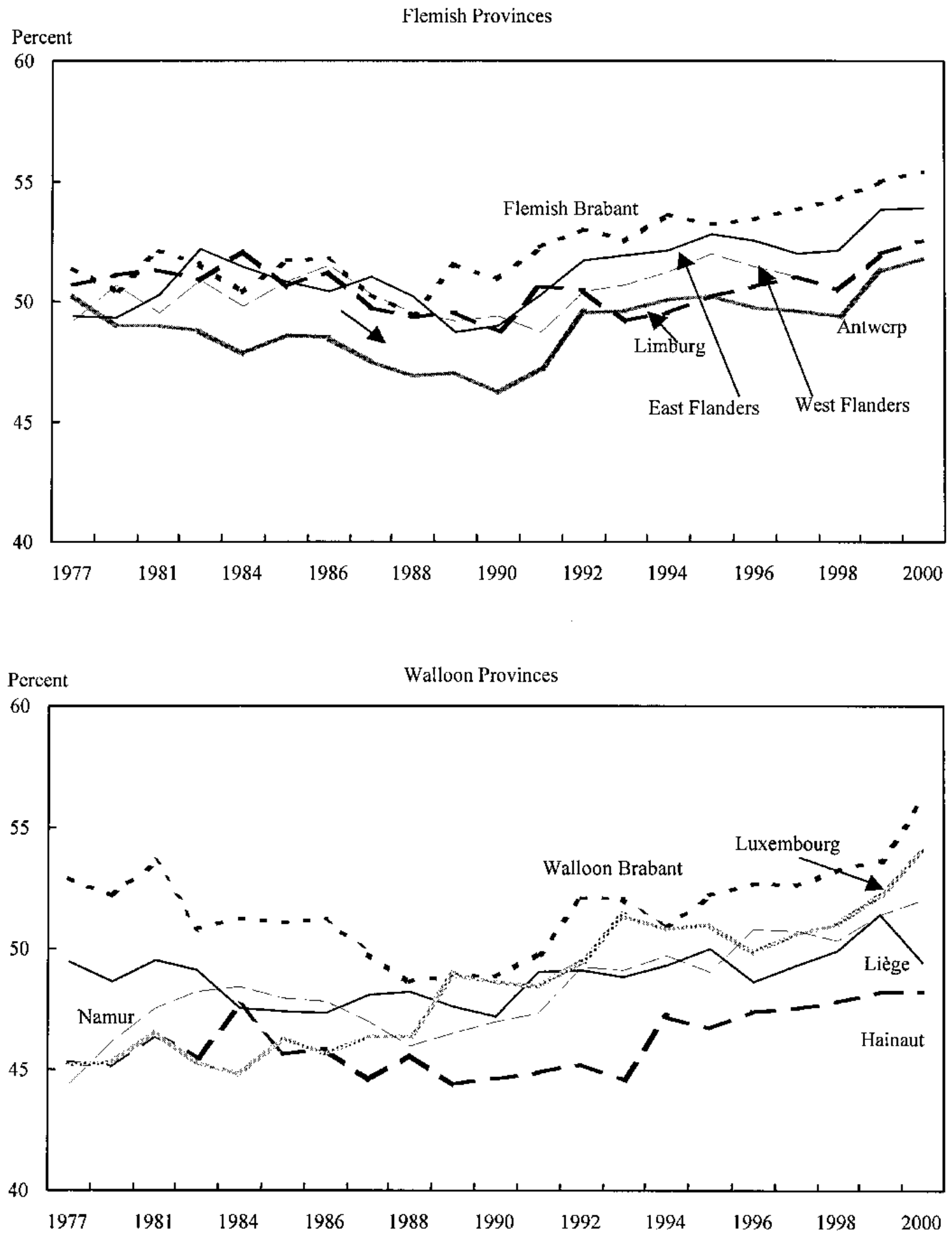

Source: Eurostat. Labor force participation rates are defined as the sum of employed and unemployed individuals divided by working-age population. Reference group is comprised of individuals between 15 and 75 years of age. Data for 1978, 1980, and 1982 are not readily available. 
Figure 6. Long-Term Unemployment

(Percent of all unemployed)
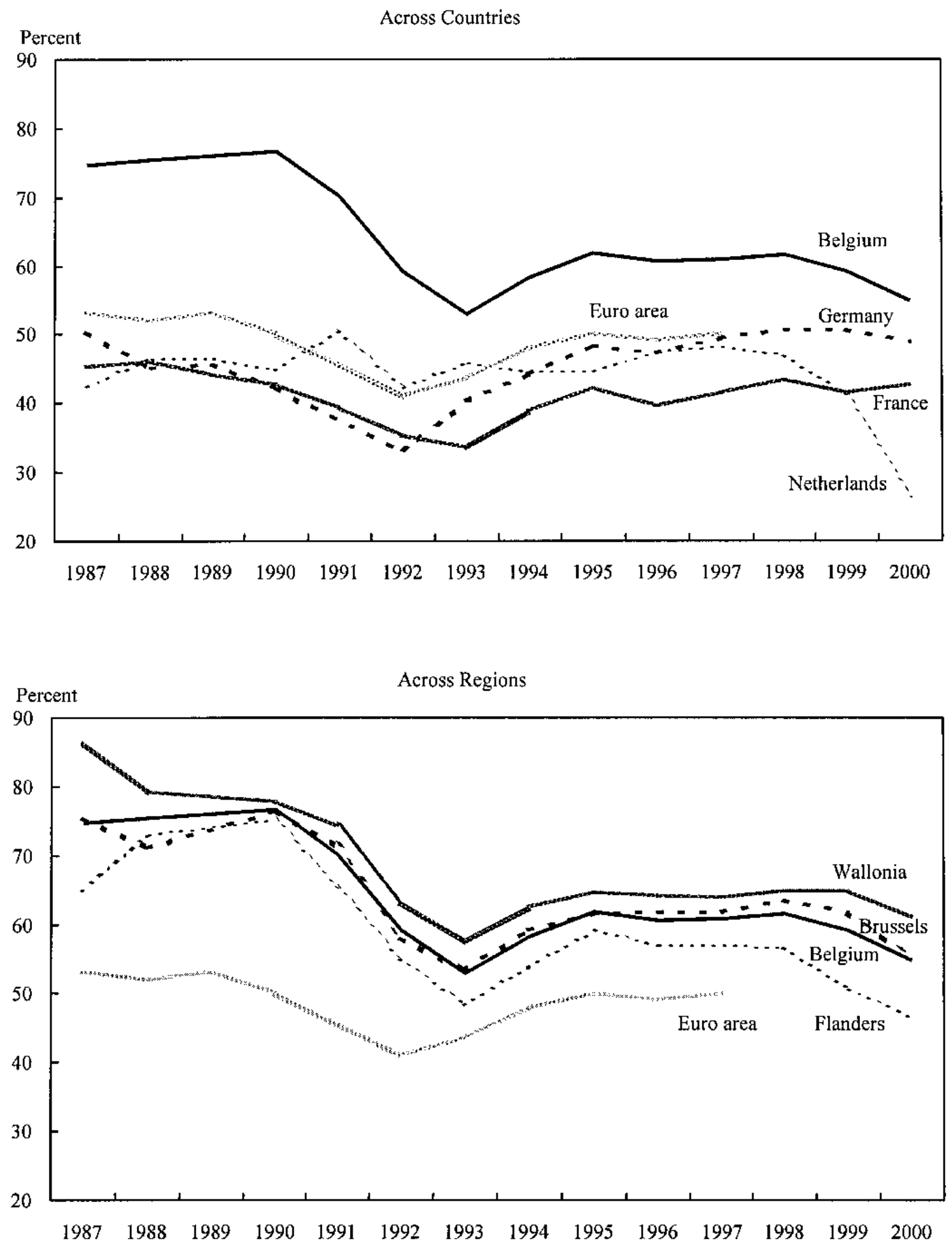

Source: Eurostat. 
Figure 7. Some Determinants of "Poverty Traps"
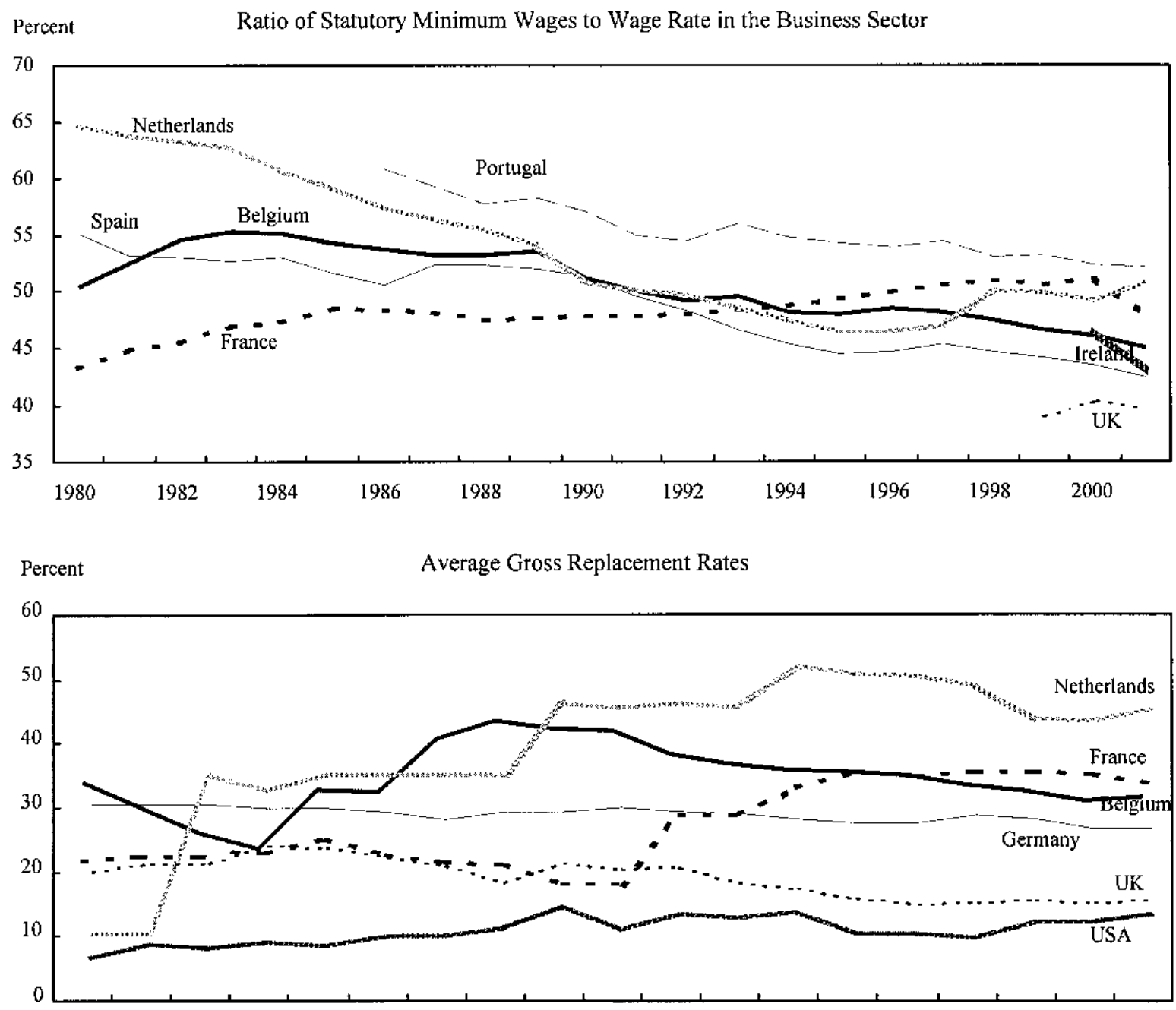

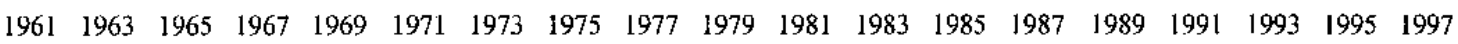

Percent Statutory Income Tax Rate on Low-Wage Earners

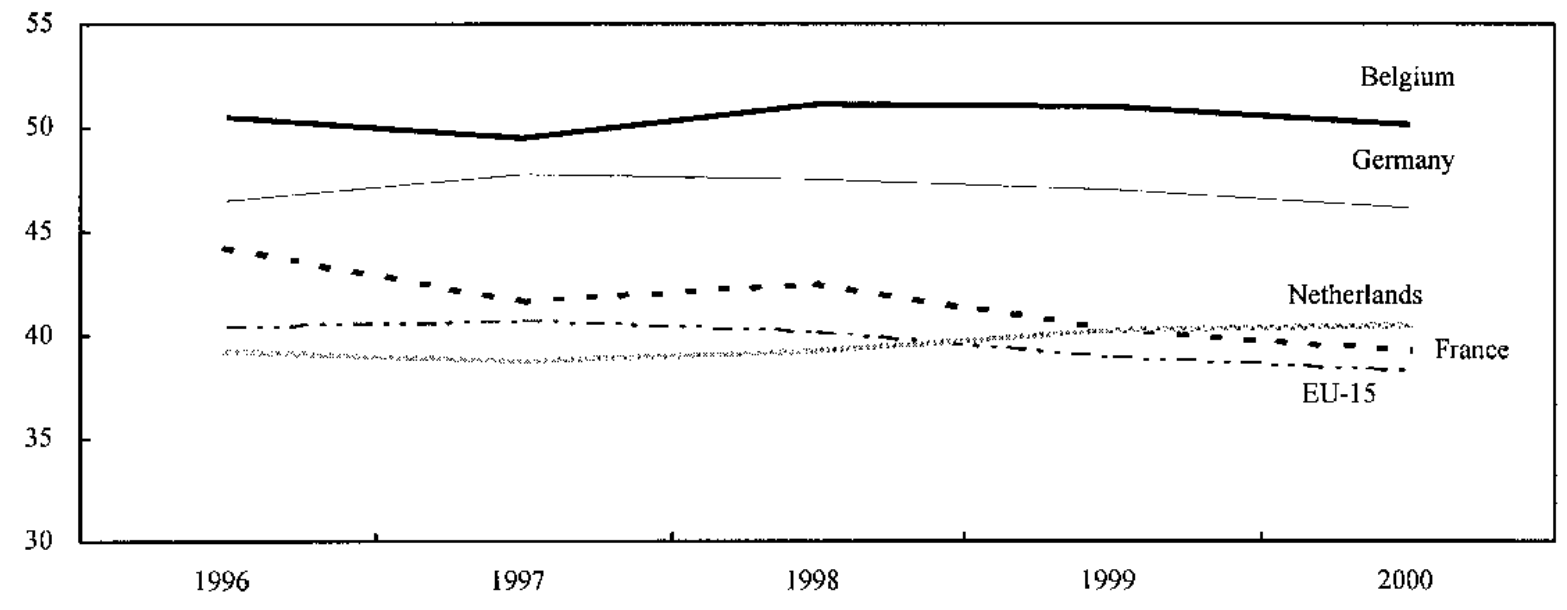

Sources: Eurostat, OECD - analytical database, OECD - tax and benefits database; and IMF staff calculations. 
Figure 8. Regional Beveridge Curves
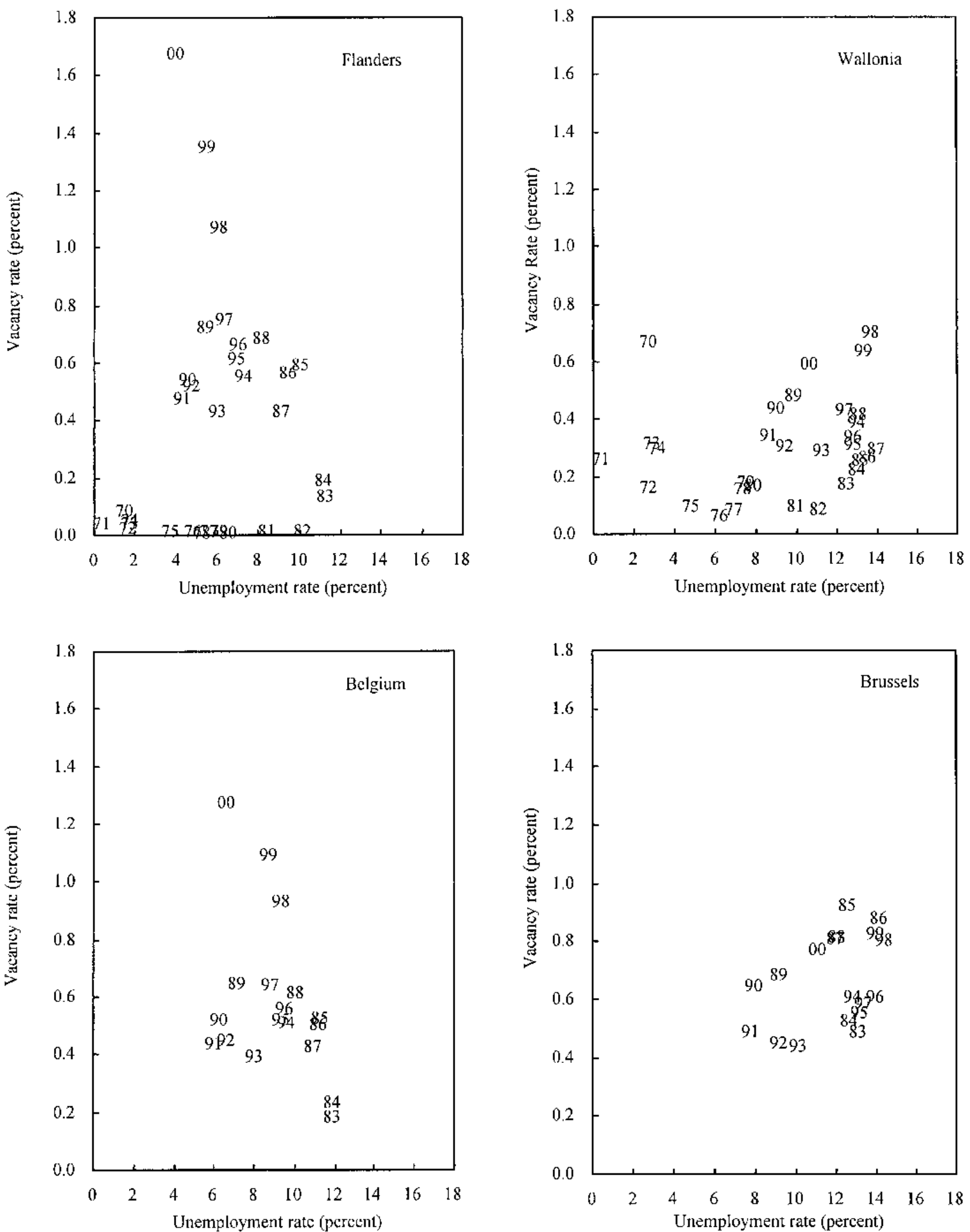

Sources: Eurostat, National Bank of Belgium, CREW and IRES (1998) and IMF staff calculations. Each vacancylunemployment pair is labeled by the relevant year. 
Figure 9. Response of Employment, Unemployment, and Labor Force Participation to an Employment Shock of 1 Percent

Effect of a shock (percent)

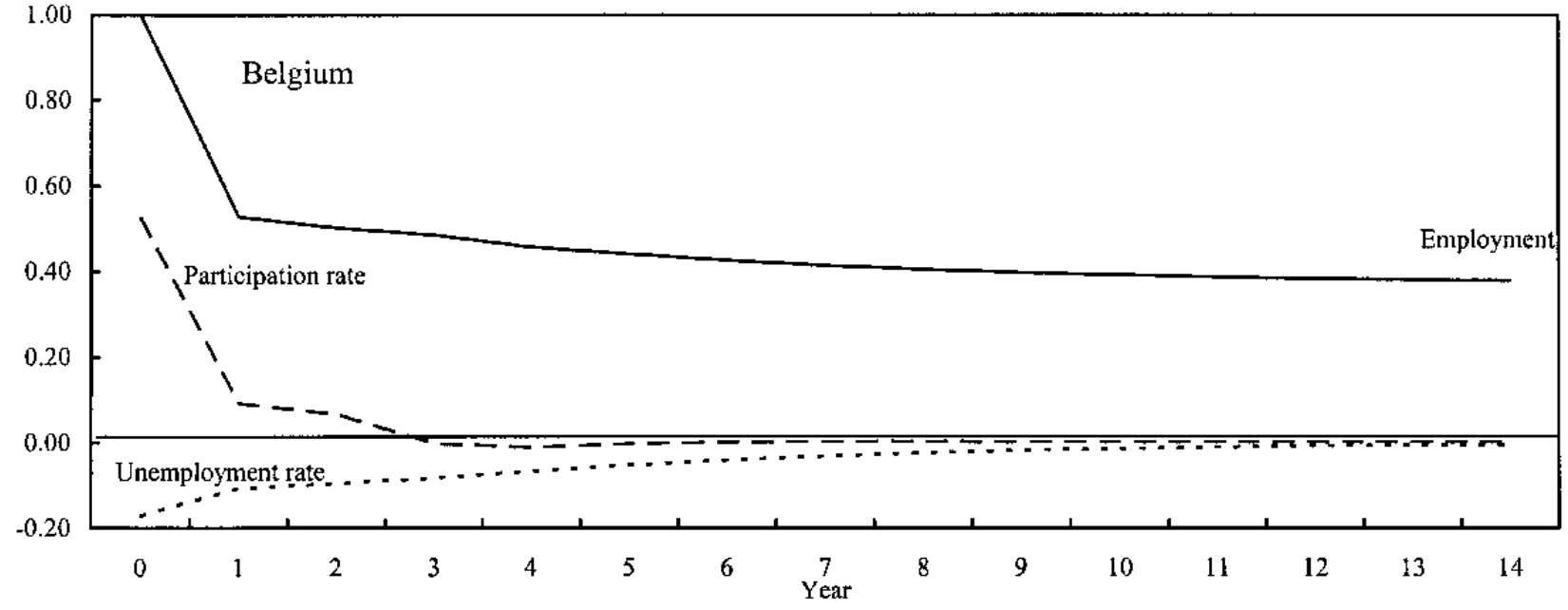

Effect of a shock (percent)

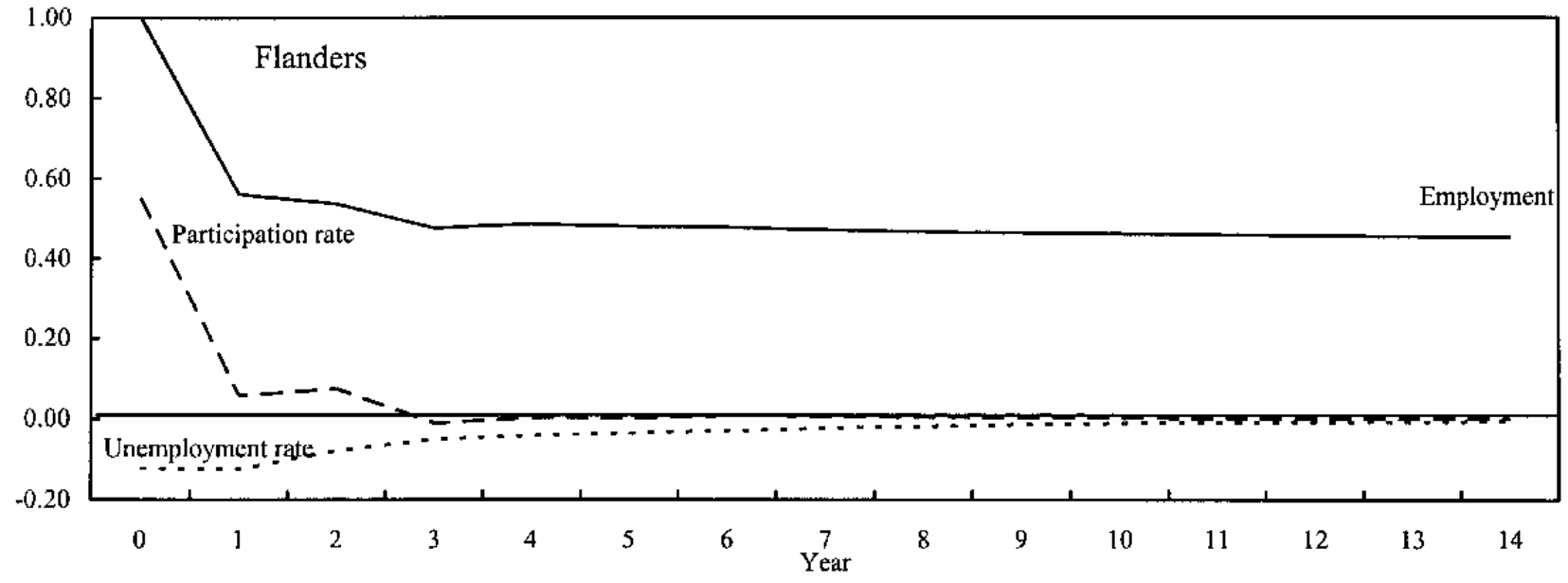

Effect of a shock (percent)

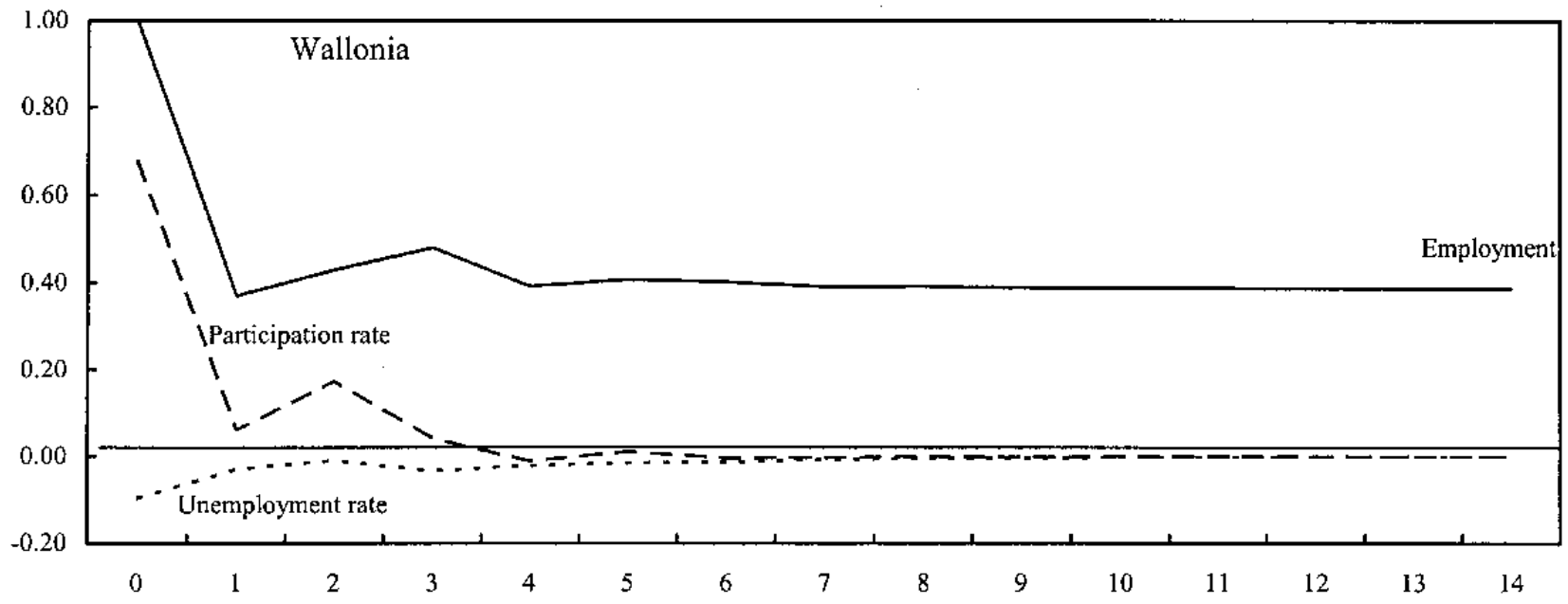

Source: IMF staff estimation based on a structural VAR using Eurostat Labor Force data. 


\section{Schematic Summary of Belgium's Geographical Organization}

\section{Regions and provinces}

A region is a geographical entity:

\section{Region of Brussels-Capital.}

Flanders comprises the five provinces of Antwerp, Flemish Brabant, West Flanders, East Flanders and Limburg. The Flemish region and community were merged at the beginning of the 1980s.

Wallonia comprises the five provinces of Walloon Brabant, Hainaut, Liège, Luxembourg, and Namur.

Note: On January 1, 1995 the province of Brabant was split into the provinces Walloon Brabant and Flemish Brabant, together with the Brussels Capital Region.

\section{Communities}

A community is a group of people (not a territory):

The Flemish community is the community of the Dutch-speaking people of the Flemish region and of the region of Brussels-Capital.

The French community is the community of the French-speaking people of the Walloon region and of the region of Brussels-Capital.

The German-speaking community is the community of the German-speaking people of nine communes located in the Walloon region along the German border. 
Belgium: Geographical Organization

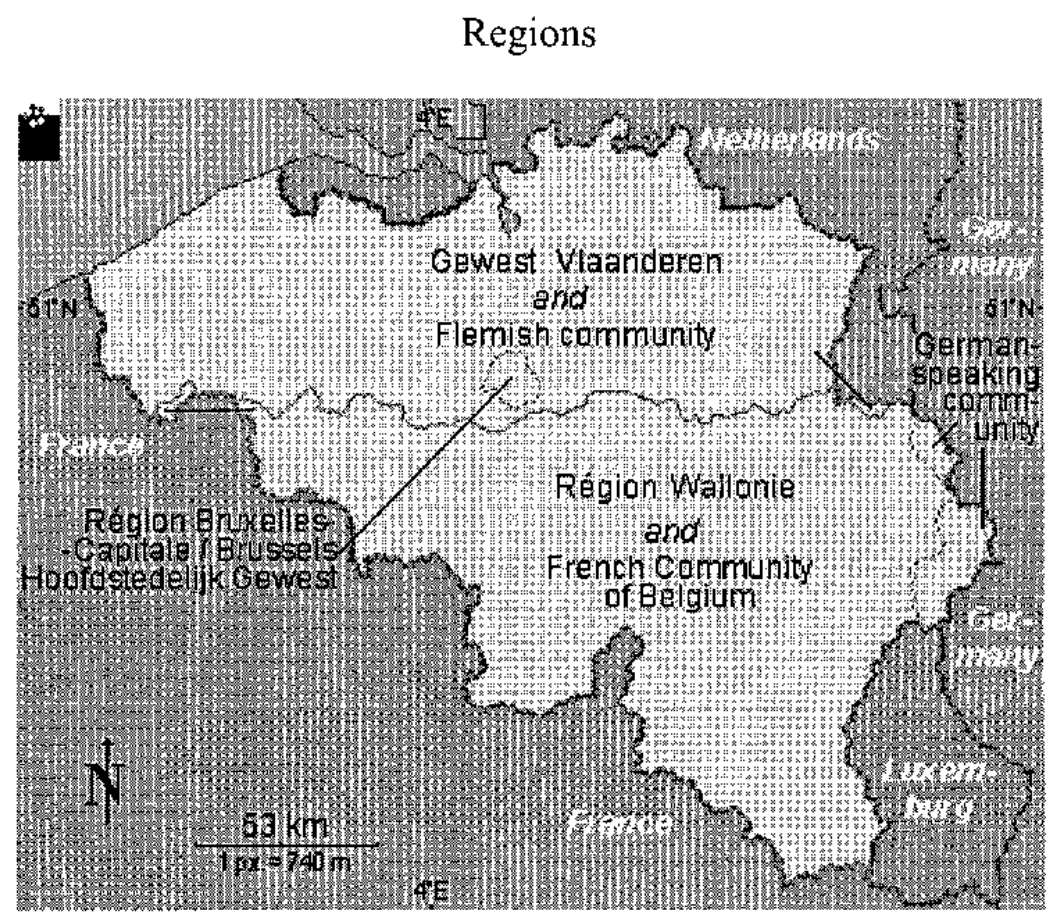

Provinces

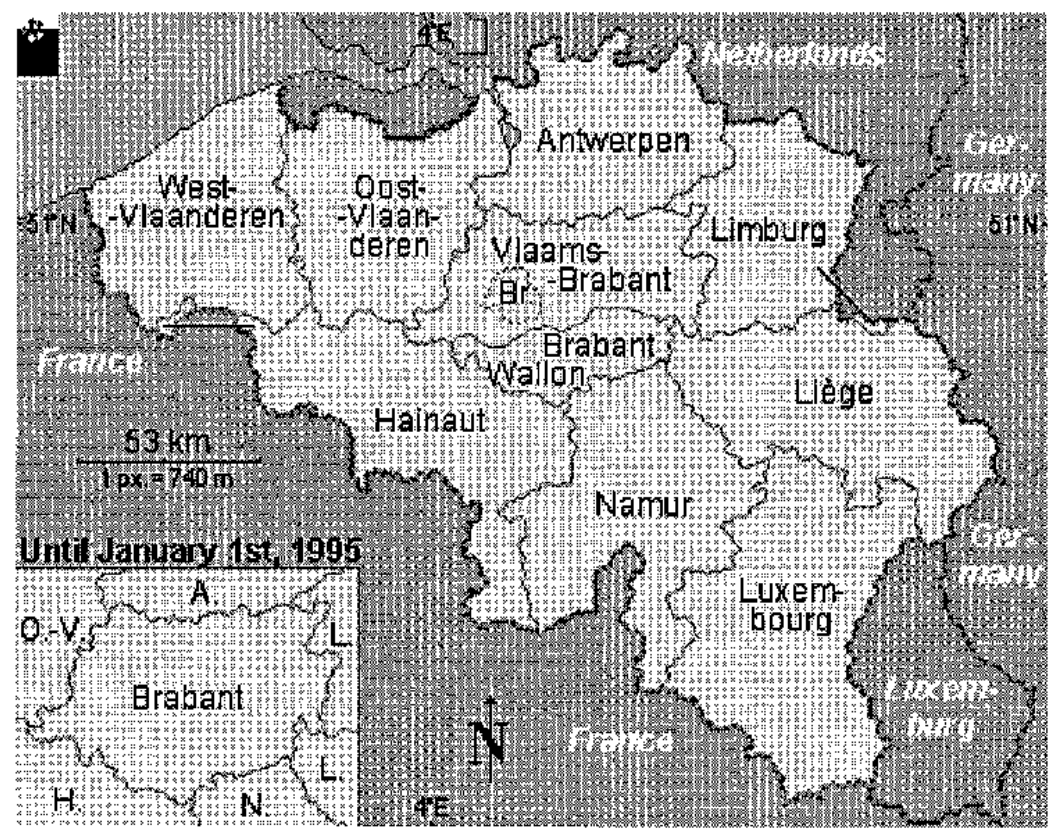

Source: FOTW GeoIndex Maps and boundary data, http://www.crwflags.com/fotw/flags/be(r.html\#map

Note: The boundaries, colors, denominations, and any other information shown on this map do not imply, on the part of the International Monetary Fund, any judgment on the legal status of any territory, or any endorsement or acceptance of such boundaries. 


\section{REFERENCES}

Bentolila, S., and J. Jimeno, 1995, "Regional Unemployment Persistence (Spain, 1976-94)," CEPR Discussion Paper No. 1259 (London: Center for Economic Policy Research).

Blanchard, O., and L. Katz, 1992, "Regional Evolutions," Brookings Papers on Economic Activity: 1, Brookings Institution, pp. 1-61.

CREW and IRES, 1998, Recherche Relative aux Facteurs Explicatifs de l'Ivolution de l'Emploi en Wallonie et de la Divergence Interrégionale pour la Période 1974-1995, Joint Report of the Centre de Recherche sur L'Economie Wallone (CREW) located at the Facultés Universitaires Notre-Dame de la Paix (F.U.N.D.P.) and the Institut de Recherches Économiques et Sociales (IRES) located at the Université Catholique de Louvain (UCL).

Decressin, J., and A. Fatás, 1995, "Regional Labor Market Dynamics in Europe," European Economic Review, Vol. 39 (December), pp. 1627-55.

Dejemeppe, M. and B. Cokx, 1998, "La Conception des Politiques en Faveur de 1'Emploi: l'Importance d'un Diagnostic des Causes du Chômage Structurel,', in Wallonie et Bruxelles: Évolution et Perspectives, $13^{\text {Ime }}$ Congrès des Economistes Belges de Langue Française, Commission 4: Portrait Socio-économique de la Belgique, (Charleroi: Centre Interuniversitaire de Formation Permanente), pp. 177-201.

Delhausse, B., and A.C. Guio, 2001, "Fonction de Salaires, Pauvreté et Marché du Travail" (unpublished; Université de Liège and SES Région Wallonne).

Docquier, F., and S. Laurent, 1996, "Les Salaires Wallons Sont-Ils Trop Ilevés? Une Étude Économétrique des Différences de Salaires entre les Régions," Tendance Économiques, (October), pp. 52-64.

_- , and S. Perelman, 1999, "Capital Humain, Emploi et Revenus du Travail: Belgique, 1992," Cahiers Économique de Bruxelles, No. 161, pp. 77-103, $1^{\text {st }}$. Quarter.

Estevão, Marcello, 2002, "Regional Labor Markets in Belgium," Selected Issues Paper, 2001 Article IV Consultation with Belgium, Washington: International Monetary Fund.

Mauro, Paolo, and Antonio Spilimbergo, 1999, "How Do the Skilled and the Unskilled Respond to Regional Shocks? The Case of Spain," Staff Papers, International Monetary Fund, Vol. 46 (March), pp. 1-17.

Organization for Economic Cooperation and Development (OECD), 1999, Benefits Systems and Work Incentives (Paris).

$\longrightarrow$, 2001, Employment Outlook, OECD, Paris. 